\title{
TRENDS IN AGILE INNOVATION MANAGEMENT
}

\section{Milan Krstic ${ }^{22}$,Ana Skorup, ${ }^{23}$,Goran Lapcevic ${ }^{24}$}

\begin{abstract}
The scope and type of applied innovations, as well as the speed of innovation by companies, today show a growing trend, which requires special efforts from the companies that claim to be leaders in the market. Therefore, these companies are forced to transform their innovative management into new forms. As an especially effective way to transform innovative management into the forefront, agile innovative management has emerged. Therefore, the theoretical desktop research of the state of development of agile innovative management from a number of perspectives has been carried out, as follows: agile innovation systems (AIS) as a phenomenon; the history of the creation of AIS; application of agile methods in companies; the basic function of agile innovation; places of agile innovation in the company; key elements of agile innovation; useful recommendations for companies that develop agile innovation; the process of agile innovation; agile behavioral approach; the uncertainty of agile innovation, and the measurement of agile innovation in companies. This paper summarizes the results of this research and gives guidelines to companies how to successfully implement agile innovation management.
\end{abstract}

KEY WORDS: research, innovation, innovation management, agility

JEL: O30, 032

UDC: 005:001.895

001.895

COBISS.SR-ID 272203020

\footnotetext{
${ }^{22}$ Faculty of Business Economics and Entrepreneurship, Belgrade, Serbia, mykrstic@gmail.com

${ }^{23}$ Faculty of Business Economics and Entrepreneurship, Belgrade, Serbia

${ }^{24}$ Higher business school of applied studies "Prof. Radomir Bojkovic, PhD“, Krusevac
} 
INTRODUCTION

The current economic paradigm - Knowledge driven economy, resulting from further evolutionary development from the previous paradigm - Economics based on the intensive application of knowledge, is basically the result of technological progress that manifests itself in civilizational practices, embodied in useful objects (products) and services, processes, organization, artifacts in all spheres of our lives (Krstić, Skorup, Lapčević, 2016). On the other hand, economics based on intensive use of knowledge in which individual product customers are in a specific way directly included in the production process with their knowledge, information, suggestions and ideas, and thereby actively participate in its realization (Krstić, Skorup, Minkov, 2016).

Knowledge-driven economy in front of businesses now sets new challenges that can be summarized in the following: the markets have become global and with new competitors; life cycles of products and services are rapidly shrinking; users are increasingly demanding; The complexity of technology is increasing. (Krstić, 2013)

In such an economy, changes have become almost everyday, which makes the entire business environment permanently changing, so the key question that is being posed today to all companies, regardless of their size, is how to survive under such conditions. In order to give a meaningful answer to that question, a theoretical desktop research was launched, which is briefly presented in this paper.

\section{RESEARCH METHODOLOGY}

The aim of the research was to explore approaches that give companies a chance to survive in a constantly changing environment.

The basic research hypothesis is that the response to the fast-changing environment of business entities should be an agile innovation.

The research applied: historical, descriptive, comparative, deductive and analytical methods.

The research has confirmed that agile innovation can enable sustainability in the long run. In this regard, the conclusions of the research presented the appropriate recommendations.

Innovative methodology is a set of methods that are applied in innovative management, that is, in the initiation and management of innovations and innovation incentives. Which of the innovative methodologies in the concrete case will be applied depends on the context (state of the environment) in which the innovation is realized, as well as our perceptions of innovation. Therefore, innovative methodologies are constantly changing and upgrading, new ones appear, and their rank of significance changes (Zakić, Bugarčić, Milovanović, 2017), (Daragahi, 2017).

The latest ranking of significance, evaluation of the first 10 innovative methodologies, (Kaminskaite J, 2016) resulted in their following order: Agile Innovative Systems, Co-Creating Values, Deep Immersion, Design Thinking, Lean Thinking, Open Innovation, Planning scenario, Six Sigma. Since Agile Innovation Systems have come to the forefront of innovative methodologies, it will be discussed in more detail.

\section{THEORETHICAL OVERVIEW OF AGILE INNOVATION SYSTEMS}

\section{Agility as a term}

The term "agile" means "fast and well-coordinated on the move; (DIC, 2017), and originates from Latin agilis, which means "it has speed in motion, turning, clever, smart" (ETY, 2017).

If the term is applied to innovative systems, the Agile Innovation System is referred to. 


\section{Brief history of the creation of agile principles}

According to (Rigby, K. D, Sutherland, J., Takeuchi, H, 2016, a) key historical points that ultimately resulted in the emergence of Agile Innovative Systems can be summarized as following:

- Francis Bacon defined the Scientific Method in 1620.

- Walter Shewhart and Edwards Deming establish the PDSA (Plan-Do-Study-Act) cycle.

- The Toyota company in the 80's introduces the Toyota Production System - the primary source of today's "Lean" thinking.

- In 1986, Hirotaka Takeuchi and Ikujiro Nonaka identified the Team-based approach, which significantly changed the process of designing and developing complex products (examples of Fuji-Xerox photocopiers, Honda Automobile Motors, Canon cameras).

- Jeff Sutherland and Ken Schwaber, in 1995, instead of a conventional "Staple" product development method, establish a new so-called "rugby" method, called "scrum" - a crowd for the ball, which allows an seemingly impossible project to end in time budget, and with fewer errors than any previous version.

- 17 programmers in 2001, who called themselves "organizational anarchists", in Snowbird, Utah, established a new name for the software design project - Agile, on the basis of which, in the meantime, was formed the Agile Alliance, a non-profit organization (with more than 30,000 members) whose aim is to promote agility in design.

Today, agility extends far beyond the information technology (IT) framework, and moreover, it has a tendency to expand to improve innovative processes, in virtually every function, of almost every industry.

Agile innovative systems are especially important for companies that have developed the Product Management, and especially within the R \& D function, and are characteristic for the development of complex products, and in particular come to terms with IT products.

\section{The place of agile innovation in innovation management}

According to the observations (Prasadi Lokuge, 2015), agile innovation can be presented as a core that links innovation, people, technology, project and outputs, Figure 1.

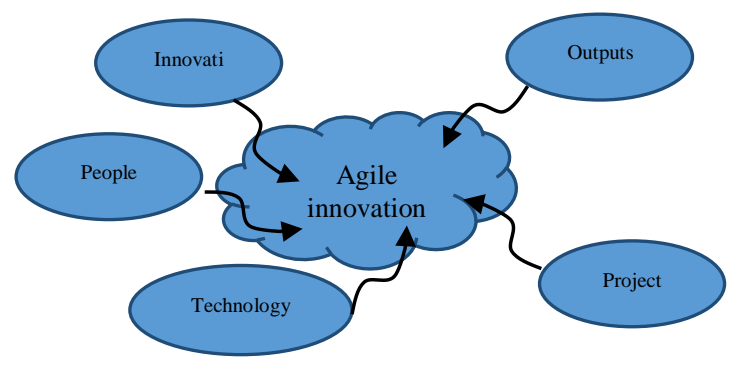

Figure 1. Agile innovation

Source: (Prasadi Lokuge, 2015)

Depending on the technology used, various types of innovations can be achieved, of which the most common are radical, incremental and desruptive innovations. In a modern competitive market, companies are usually unable to tolerate desruptive innovations, because they are very 
expensive and very risky. This is why companies, using the available organizational technologies, mainly implement incremental or radical innovations. Key differences between incremental and radical innovations are presented in Table 1.

Table 1: Characteristics of radical and incremental innovation, Source (Prasadi Lokuge, 2015)

\begin{tabular}{|l|l|}
\hline Incremental innovation & Radical innovation \\
\hline $\begin{array}{l}\text { continuous (linear improvement of value } \\
\text { acquired by the customer) }\end{array}$ & $\begin{array}{l}\text { discontinuous (with or without predecessor; } \\
\text { essential, nonlinear improvement obtained } \\
\text { by the customer) }\end{array}$ \\
\hline based on old technology & based on new technologies \\
\hline dominant design unchanged & leads to a new dominant design \\
\hline does not lead to a paradigm shift & can lead to a paradigm shift \\
\hline implies a low level of uncertainty & implies a high level of uncertainty \\
\hline improvement of existing characteristics & $\begin{array}{l}\text { introduces a whole new set of performance } \\
\text { features }\end{array}$ \\
\hline $\begin{array}{l}\text { existing organization and qualifications are } \\
\text { sufficient }\end{array}$ & $\begin{array}{l}\text { requires education, new organization and } \\
\text { skills }\end{array}$ \\
\hline $\begin{array}{l}\text { the result of a rational response or necessity } \\
\text { result of chance or R \& D policy, not } \\
\text { necessity }\end{array}$ \\
\hline $\begin{array}{l}\text { driven by market pull (important in the } \\
\text { advanced stage of technology) }\end{array}$ & $\begin{array}{l}\text { driven by technology (important in the early } \\
\text { stage of technology) }\end{array}$ \\
\hline $\begin{array}{l}\text { in order to achieve short-term economic } \\
\text { goals }\end{array}$ & $\begin{array}{l}\text { in order to achieve long-term economic } \\
\text { goals }\end{array}$ \\
\hline
\end{tabular}

The place and role of agile innovation in relation to incremental and radical innovation are presented in Table 2 .

Table 2: Comparison of innovation types

\begin{tabular}{|l|l|l|}
\hline Incremental innovation & Radical innovation & Agile innovation \\
\hline $\begin{array}{l}\text { Continuous (linear } \\
\text { improvement of value } \\
\text { acquired by the customer) }\end{array}$ & $\begin{array}{l}\text { discontinuous (with or } \\
\text { without predecessor; } \\
\text { essential, non-linear } \\
\text { improvement) }\end{array}$ & ad-hoc \\
\hline based on old technology & based on new technology & $\begin{array}{l}\text { based on old and on new } \\
\text { technology }\end{array}$ \\
\hline dominant design unchanged & $\begin{array}{l}\text { leads to a new dominant } \\
\text { design }\end{array}$ & dominant design expanded \\
\hline $\begin{array}{l}\text { does not lead to a paradigm } \\
\text { shift }\end{array}$ & can lead to a paradigm shift & $\begin{array}{l}\text { can lead to moderate } \\
\text { changes in the paradigm }\end{array}$ \\
\hline $\begin{array}{l}\text { implies a low level of } \\
\text { uncertainty }\end{array}$ & $\begin{array}{l}\text { implies a high level of } \\
\text { uncertainty } \\
\text { uncertainty }\end{array}$ \\
\hline $\begin{array}{l}\text { improvement of existing } \\
\text { characteristics }\end{array}$ & $\begin{array}{l}\text { introduces a new set of } \\
\text { features }\end{array}$ & $\begin{array}{l}\text { leads to the expansion of } \\
\text { existing characteristics }\end{array}$ \\
\hline $\begin{array}{l}\text { existing organization and } \\
\text { qualification are sufficient }\end{array}$ & $\begin{array}{l}\text { there is a need for additional } \\
\text { education, new organization } \\
\text { and new skills }\end{array}$ & $\begin{array}{l}\text { there is a need for smaller or } \\
\text { specialized skills }\end{array}$ \\
\hline
\end{tabular}




\begin{tabular}{|l|l|l|}
\hline $\begin{array}{l}\text { The result is a rational } \\
\text { response to needs }\end{array}$ & $\begin{array}{l}\text { The result is the coincidence } \\
\text { or the impact of R\&D } \\
\text { policy rather than need }\end{array}$ & attributed to the agility \\
\hline $\begin{array}{l}\text { driven by market dragging } \\
\text { (important in the advanced } \\
\text { stage of technology) }\end{array}$ & $\begin{array}{l}\text { driven by pushing } \\
\text { technology (important in the } \\
\text { early stage of technology) }\end{array}$ & $\begin{array}{l}\text { driven by competition on } \\
\text { the market and by } \\
\text { technological advancement }\end{array}$ \\
\hline $\begin{array}{l}\text { in order to achieve short- } \\
\text { term economic goals }\end{array}$ & $\begin{array}{l}\text { in order to achieve long- } \\
\text { term economic goals }\end{array}$ & $\begin{array}{l}\text { in order to achieve a quick } \\
\text { return }\end{array}$ \\
\hline
\end{tabular}

Source: (Prasadi Lokuge, 2015)

\section{Possibilities for using agile methods}

Agile methods are being successfully applied, and only some typical examples of application in different areas will be listed here (Rigby, Sutherland, Takeuchi, 2016, b):

- National Public Radio uses agile methods for creating new programs,

- John Deere uses agile methods to develop new machines, $\mathrm{i}$

- Saab uses agile methods to produce new combat aircraft,

- Intronis, a leader in cloud backup services, uses agile marketing methods,

- C.H. Robinson, a global leader in logistic services, uses agile methods in human resource management,

- Bell Winery uses agile methods from wine production to warehouse,

- GE uses agile methods to accelerate public transition from the 20th century conglomerate to the "digital and industrial company" of the 21 st century.

\section{Characteristics of agile innovation}

Agile innovation is a specific "guide in the field for designing and implementing effective innovation strategies by strengthening the classical methodology of innovation with the Agile process. In order to facilitate Agile collaborative processes, self-organized and self-optimizing teams can be formed in the organization to better solve complex problems and create desruptive innovations" (Langdon, Moses, Po Chi, 2014). In this sense, three key functions of Agile innovation are:

(1) Achieve maximum speed in innovative efforts. Agile innovations support the effective development of created ideas and their productive implementation, through a common innovation, from leadership to operation.

(2) Risk reduction. Agile innovation encourages the creation of a culture of innovation, and through increased collaboration between all actors in innovation, risk can be reduced (see section 1.9).

(3) Engaging the entire organization in creating and developing the best ideas, since agile innovation promotes the principles of integration. Effective innovation, as a rule, does not happen by chance, but it is the result of the deliberate design and improvement of the organization's innovation.

\section{Elements of Agile Innovation}

The practice of innovative management shows a rule that innovation is accompanied by organizational changes. However, according to (IVP, 2015), thanks to the Agile Innovative System - AIS, companies can improve their innovative activities even without the need for major organizational changes. The condition for this is the creation of a flexible team and assignment of authorization to the team, for the implementation of an innovative task. In this way, AIS can 
be thought of as an execution plan that will be implemented through Open Innovations. Within the AIS, three subsystems can be identified (Figure 2): Growth, Accel and Scouting.

The subsystem Growth focuses on development opportunities, as a company that needs to build growth on the basis of new innovative activities, as well as companies that already realize innovative activities through acceleration of team effort.

The Accel subsystem serves to build new platforms based on the iterative "market-testing" approach, which quantifies the risk and reduces the uncertainty of organized investment.

The Scouting subsystem enables teams of internal technology experts to proactively identify destructive technologies, which help predict new growth platforms.

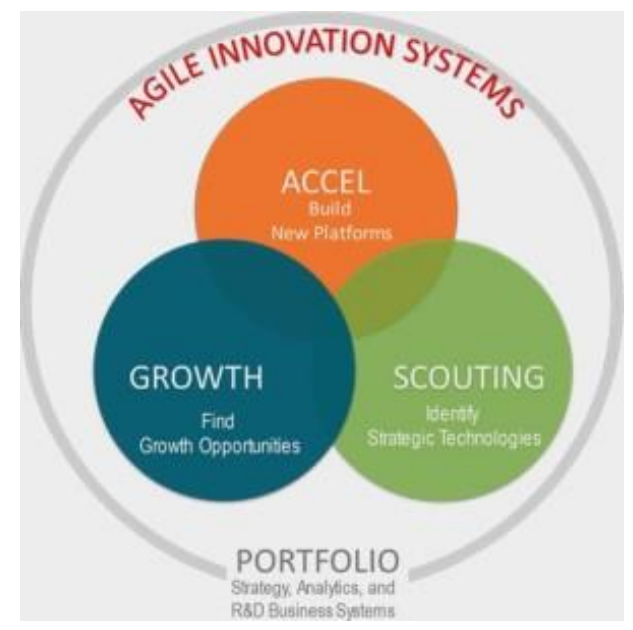

Figure 2. Agile innovation systems

Source: (IVP, 2015)

\section{Agile Innovation Process}

Each innovation is realized through a specific innovative process, and in this sense Agile Innovation is realized through the Process of Agile Innovation, Figure 3.

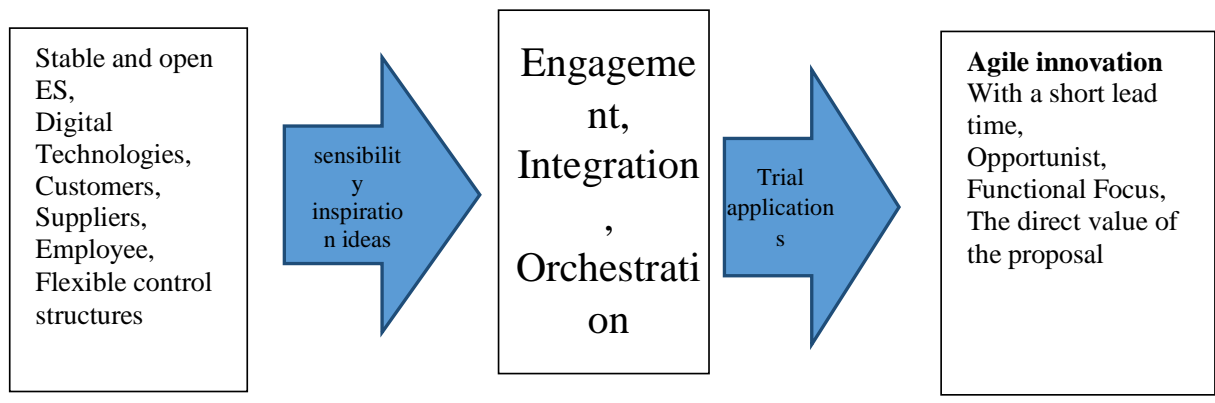

Figure 3. The process of agile innovation

Source: (Prasadi Lokuge, 2015)

Hereinafter, the process of agile innovation will be elaborated in detail.

Figure 3, Block 1 shows the important structural elements of the agile process, as follows: 
Innovative platform. The requirement for the realization of innovation is the existence of an innovative platform. Innovative platform is a business system, which in Figure 3 is represented as a stable and open Enterprise System (ES), which enables innovation.

Digital technologies. Digital technologies today are helping and inspiring creative thinking and innovative challenges. Companies are able to assess their capacities and capabilities and on the basis of that they choose the most appropriate technologies for improving a particular business function or business process.

Eco-system. By analogy with the bio-ecological system, the eco-system of the business system consists of the following stakeholders, that is, the stakeholders of the ES, namely: customers, suppliers and employees. They all have a share in the realization of agile innovation.

Flexible control structures. Experience, especially with the IT governance structures, highlighted the importance of organizational design, where the need for more flexible management structures favoring innovation is especially emphasized.

The direction of Block 1 is towards sensibility (feeling) for the needs of the market, towards inspiration and ideas, or creation of ideas.

Block 2 includes the following structural elements of the agile process, as follows:

Engagement. Engagement refers to the engagement of all actors involved in the innovation process.

Integration. In order to enable the engagement of all stakeholders, it is necessary to integrate their efforts.

Orchestration. In order for the integrated efforts to provide a synergistic effect, it is necessary to ensure their orchestration, or successful conduct.

The direction of Block 2 is towards the trial of application, since in the case of agile innovation, the trial takes place synchronously with its formation.

Block 3 includes structural elements of an agile process that relate to the key characteristics of agile innovation, such as: short implementation time, opportunistic innovation, functional focus, and direct value of the innovation proposal.

\section{Agile approaches}

Agile access can be best viewed on an IT iterative approach, or an access to software delivery, that is used by companies that develop software. (Rasmusson J, 2017)

In the traditional software development, Figure 4, there is a continuous one-by-one activity - analysis, design, coding and, finally, testing. In this case, software testing is realized after all the activities that precede it have been realized.

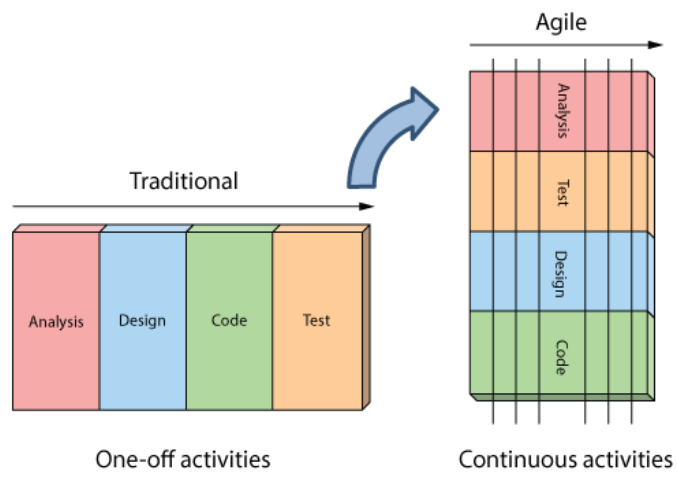

Figure 4: Traditional and agile software development Source: (Rasmusson J, 2017) 
Unlike the traditional approach, Figure 4, in the agile approach, all the above activities analysis, design, coding and testing - are carried out continuously and simultaneously throughout the development project. In this way, the following benefits are achieved:

- The quality of the project is improving, as its testing starts from the first day of software development;

- The visibility of the project is improving, because the project immediately becomes visible to the extent that a part of its functions has been built;

- the risk is reduced because user feedback is relatively early; and

- End-users are satisfied because they can introduce changes in the project without the obligation to pay the additional costs.

\section{Uncertainty with agile innovation}

Risk and uncertainty are regular followers of every innovative project, and in that sense agile innovation. This especially due to the fact that the environment conditions of the business entity that innovates and the innovations change rapidly, which puts additional problems ahead of the designers. In order to assess the risk of agile innovation, an Uncertainty cone can be used as an analogue, which is present in IT innovation or software design.

According to (CON, 2017), at the earliest stage of the software designing project, specific details regarding the nature of the software, details of specific requirements, details of the final solution, project plan, details of work engagement and other variables of the project, as a rule, are unclear. The variability in the above details contributes to the variability in the assessment of the project as a whole. As the sources of variabillity that concern the details are investigated and fixed, so the variability within the project decreases, which also leads to a decrease in uncertainty. This phenomenon is known as the "Cone of Uncertainty", which is shown by the diagram of the cone of uncertainty, Figure 5.

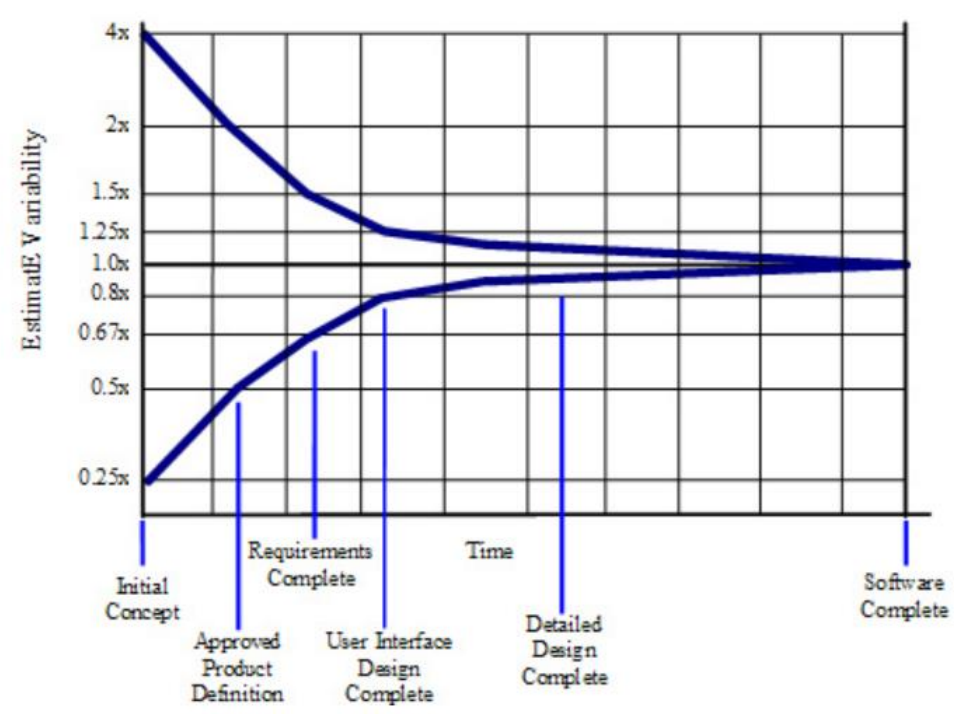

Figure 5: Cone of Uncertainty

Source: (CON, 2017)

The horizontal axis of the diagram is the time axis of the duration of the project. It features characteristic project points (milestones), such as: the end time of the initial concept, the time 
when product definition was adopted, the time when the project requirements were completed, the time when the user interface was completed, and so on.

The vertical axis of the diagram is the estimation of variability and is expressed by the degree of error that can be found in the assessments made by qualified assessors within the milestones in the project. Estimates can refer to the costs of a particular set of functions, the effort to invest in the realization of the set of functions, and the like. As is evident from Figure 5, the estimates made earlier in the project are those that are susceptible to a greater degree of error. Thus, estimates of the completion time of the initial concept may be incorrect with a factor of $4 x$, an estimate of the time when the product definition may be incorrect with a factor $2 \mathrm{x}$, an estimate of the time when the user interface is completed with the factor of $1.25 \mathrm{x}$, and so on, with estimation in later phase of the project, the error is less.

In this regard, the presented uncertainty model present in software design can be generalized and applied to Agile systems, since they represent uncertainty especially in terms of changing initial conditions.

\section{Measurement of agile innovation parameters}

Management process assumes that four key functions are implemented, namely: planning, organizing, leading, and controlling. The last - control is missing, unless an adequate performance measurement is established. This also applies to innovation management. Hence, the issue of innovative metrics, which deals with benchmarking at the national or company level, is gaining in importance, and it is no wonder that it has a longer pre-history. So far, four generations of innovative metrics have been developed, Table 3, from which it is evident that new indicators have been introduced, which measure innovation. Thus, the first generation of the indicators is characterized by inputs for innovation, the second generation by outputs, the third generation by innovation parameters, and the fourth generation by process indicators.

Table 3. The four generations of innovative metrics

\begin{tabular}{|c|c|c|c|}
\hline $\begin{array}{c}\text { First generation } \\
\text { (1950s-1960s) }\end{array}$ & $\begin{array}{c}\text { Second generation } \\
(\mathbf{1 9 7 0 s - 1 9 8 0 s )}\end{array}$ & $\begin{array}{c}\text { Third generation } \\
(\mathbf{1 9 9 0 s})\end{array}$ & $\begin{array}{c}\text { Fourth generation } \\
(\mathbf{2 0 0 0 s})\end{array}$ \\
\hline Input indicators & Output indicators & Innovation indicators & Process indicators \\
\hline R\&D expenditure & Patents & Innovation surveys & Knowledge \\
S\&T personnel & Bibliometrics & Indexing & Intangibles \\
Capital & Products & Benchmarking & Networks \\
Technology & Quality change & Human resources & Demand \\
intensity & & ICT indicators & Clusters \\
& & & Management \\
& & & techniques \\
& & & Risk/return \\
& & & System dynamics \\
\hline
\end{tabular}

Source: (Arasimhalu, 2011)

The emergence of agile innovative systems has led to the development of a new methodology for measuring the agility of innovative management in companies, which differs from the previous four generations of indicators (Arasimhalu, 2011). Key measurement targets and indicators for measuring agility in innovative management in the company are shown in Table 4. 
Table 4. Objectives and indicators for measuring agility in innovative management in the company

\begin{tabular}{|l|l|l|}
\hline Goals & Indicators & Comment \\
\hline $\begin{array}{l}\text { Maximizing the efficiency } \\
\text { of innovative management }\end{array}$ & $\begin{array}{l}\text { Agile Innovation } \\
\text { Management Index (AIMI) }\end{array}$ & $\begin{array}{l}\text { Synthesized indicator of the } \\
\text { agility of innovative } \\
\text { management }\end{array}$ \\
\hline $\begin{array}{l}\text { The time needed to form an } \\
\text { innovative team }\end{array}$ & $\begin{array}{l}\text { Innovation Response Index } \\
\text { (IRI) }\end{array}$ & $\begin{array}{l}\text { A measure of how quickly a } \\
\text { team for design and delivery } \\
\text { of innovation can be formed }\end{array}$ \\
\hline $\begin{array}{l}\text { Minimizing the cycle time } \\
\text { from idea to market (I2M) }\end{array}$ & $\begin{array}{l}\text { Agile Innovation } \\
\text { Development Index (AIDI) }\end{array}$ & $\begin{array}{l}\text { The amount of time it takes } \\
\text { for an innovative team to } \\
\text { develop and deliver } \\
\text { innovation }\end{array}$ \\
\hline
\end{tabular}

Source: Authors, based on (Arasimhalu, 2011)

The structure of Agile Innovation Management Index is presented in Figure 6, from which it is evident that the Agile Innovation Management Index (AIMI) is built from two indexes - the Innovation Response Index (IRI) and the Agile Innovation Development Index (AIDI). It is evident from Figure 6 that two indexes - the Innovative Culture Index (ICI) and the Innovation Depth Index (IDI) are included in the formation of the Innovation Response Index (IRI). In addition, the Innovation Culture Index (ICI) is built from three indexes - Innovation Training effectiveness (ITE), Innovation Quality and Capacity (IQC) and Management Commitment to Innovation (MCI). A questionnaire with a total of 18 questions (variables) is involved in the formation of these indexes.

Companies should periodically calculate their indexes of innovative management - Agile Innovation Management Index (AIMI), Innovation Response Index (IRI), and Agile Innovation Development Index (AIDI), and compare them:

- with indexes for the previous period (it is recommended to be done every year),

- with indexes for comparable companies in the same industry.

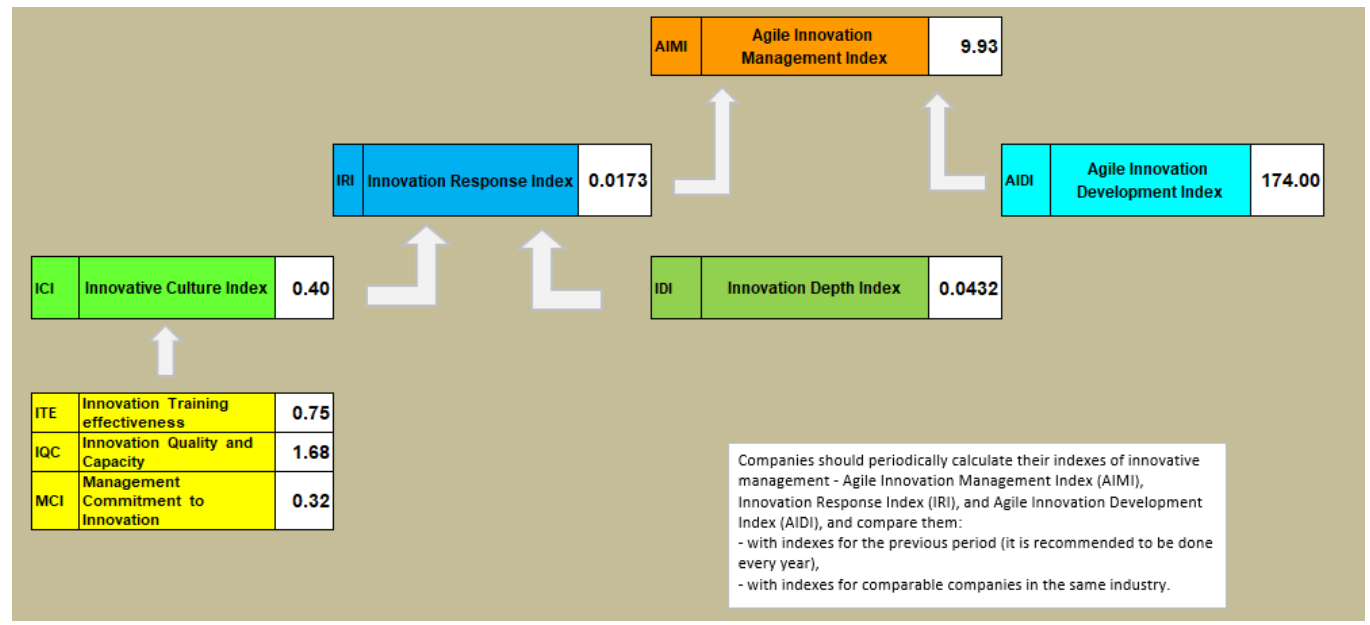

Figure 6: Excel tool for determining the company's agility in innovation management,

Source: Authors, based on (Arasimhalu, 2011) 


\section{DISCUSSION}

On the basis of the conducted desktop research, it can be concluded that agile innovation has largely developed into innovative management and confirmed its introduction. On the basis of the previous review, certain recommendations can be made for companies that intend to develop agile innovations. In that sense, leaders in companies, if they want to use agile potential, should adopt the following key practical recommendations (Rigby, Sutherland , Takeuchi , 2016, b), as follows:

1. Find out how agility really works

Leaders of agile behavior must find out how agility really works. For this knowledge of importance is the realization that the values and principles of Agile innovation include:

- scrum, which emphasizes creative and adaptable team work in solving complex problems;

- lean development, which focuses on the continuous elimination of all losses; and

- kanban, which concentrates on reducing lap times and the amount of work in the process.

2. Understand where agility works`

Leaders of agile behavior should understand where agility has an effect. For assessing the condition where agility works or where it does not work, Table 5 which presents key states for agility can be very useful.

\section{Table 5: Favorable and unfavorable conditions for agility}

\begin{tabular}{|l|l|l|}
\hline STATE & $\begin{array}{l}\text { FAVORABLE CONDITIONS } \\
\text { FOR AGILITY }\end{array}$ & $\begin{array}{l}\text { UNFAVORABLE CONDITIONS } \\
\text { FOR AGILITY }\end{array}$ \\
\hline $\begin{array}{l}\text { Market } \\
\text { environment }\end{array}$ & $\begin{array}{l}\text { User Preferences and elective options } \\
\text { change frequently }\end{array}$ & User preferences are stable \\
\hline User involvement & $\begin{array}{l}\text { Close cooperation and quick feedback are } \\
\text { possible. } \\
\text { Users know best what they want because } \\
\text { the process is progressing. }\end{array}$ & $\begin{array}{l}\text { The requirements are clear at the very } \\
\text { beginning and will remain stable. } \\
\text { Customers are unavailable for permanent } \\
\text { cooperation. }\end{array}$ \\
\hline $\begin{array}{l}\text { The type of } \\
\text { innovation }\end{array}$ & $\begin{array}{l}\text { The problems are complex, the choices } \\
\text { are unknown, and the scope is not clearly } \\
\text { defined. Product specifications can be } \\
\text { changed. Creative breakthroughs and time } \\
\text { to market are important. Cross-functional } \\
\text { cooperation is vital. }\end{array}$ & $\begin{array}{l}\text { Similar work has not been done before, } \\
\text { and innovators believe that solutions are } \\
\text { clear. Detailed specifications and work } \\
\text { should be followed. Problems can be } \\
\text { solved sequentially in functional } \\
\text { organizational units. }\end{array}$ \\
\hline $\begin{array}{l}\text { Modularization of } \\
\text { work }\end{array}$ & $\begin{array}{l}\text { Incremental events have value, and users } \\
\text { can use them. } \\
\text { Work can be divided into parts and } \\
\text { implemented in fast, iterative cycles. } \\
\text { Later changes can be solved. }\end{array}$ & $\begin{array}{l}\text { Users can not start testing parts of the } \\
\text { product until everything is finished. } \\
\text { Late changes are expensive or impossible. }\end{array}$ \\
\hline $\begin{array}{l}\text { The impact of the } \\
\text { temporary error }\end{array}$ & \begin{tabular}{l} 
Provide precious learning. \\
\hline
\end{tabular} & It can be catastrophic. \\
\hline
\end{tabular}

Source: (Rigby, Sutherland, Takeuchi, 2016, b)

Routine and predictable tasks, in which impact assessments, press interviews, factory visits, customers and suppliers, etc. can be classified, do not fall under the category of agility tasks. 
Non-routine and hard-to-predict tasks, which can include development strategies, resource allocation, pervasive innovation, and improved organizational cooperation, etc., fall into the category of agility tasks.

\section{Agility start with small increments}

Leaders of agility, that is, the leaders who are most successful in agility management, usually introduce agility with small increments, usually at the IT sector, since programmers are the largest acceptors of agility, and they extend agility to other functions in the organization.

\section{Agility requires stable teams}

The experience of introducing agile innovations indicates that it is desirable that the deployment teams are relatively stable. If the teams are stable, or if there is no change in team members, the teams are more productive even by $60 \%$, compared to teams that change team members.

\section{Agility should be practiced from top management}

Experience has shown that agility should not be practiced only with innovative teams that carry out innovative activities. It is very important that top management also learns the principles of agility, and applies them as an agile team, as this can achieve the far-reaching benefits of their company.

\section{Agliness should destroy organizational barriers}

In overcoming the barriers of agile behavior, very benefitial can be a management style that helps functional managers turn into general managers, and the strategies of companies and their organizations to evolve, from managers sealed into organizational units, into managers who become fighters for power and resources in common cross- functional teams of the company.

Leaders who pretend to be leaders in agile behavior should learn to, instead of ordering, build leadership on issues addressed to agile teams, such as "What do you recommend?" and "How can this be tested?" and similar.

\section{CONCLUSION}

In this paper, the results of desktop theoretical research are presented in the shortened scope in order to explore approaches that give companies a chance to survive in a constantly changing environment.

The basic assumption of research has been confirmed that agile innovation is the right response to the fast-changing environment of business entities.

In the present research focus was on companies - large corporations, which have developed $R \& D$ function.

The possibilities for the rational application of the principles of agility when it comes to companies in the category of micro, small and medium-sized companies remain yet to be explored.

\section{REFERENCES}

[1] Arasimhalu, A.D. (2011). Agile Innovation Management, Available a. International Society for Professional Innovation Management Innovation Symposium, Research Collection School Of Information Systems. Wellington, New Zealand, 29 November - 2 December 2011: http://ink.library.smu.edu.sg/sis_research/1463.

[2] CON. (2017). The Cone of Uncertainty. Retrieved from Construx: http://www.construx.com/Thought_Leadership/Books/The_Cone_of_Uncertainty/ 29.5.2017

[3] Daragahi, G. (2017). The impact of innovation on customer satisfaction: A study of the cosmetics producer in Tehran. International Review, Faculty of Business Economics and 
Entrepreneurship, Belgrade, Filodiritto Editore, Bologna, 2017 No. 1-2, 2017. pp. 121-132. 10.5937/intrev1702121D.

[4] DIC. (2017). agile. Retrieved from http://www.dictionary.com/browse/agile?s=t, 30.05.2017

[5] ETY. (2017). agile (adj.) . Retrieved from http://www.etymonline.com/index.php?allowed_in_frame=0\&search=agile, 30.05.2017

[6] IVP. (2015, ). Agile Innovation Systems ${ }^{\mathrm{TM}}$ (AIS),. Retrieved from 2.5.2017., InnoVentures, Pittsburgh, PA: http://strategicinnoventures.com/about-us/agile-innovation-systems/,

[7] Kaminskaite J. (2016). Retrieved from Top 10 Innovation Methodologies: https://www.giminstitute.org/top-10-innovation-methodologies/?page-img266681=1, 7.5.2017

[8] Krstic M., Skorup A., Minkov Đ., 2016., Application Of The Evolution Theory In Modeling Of Innovation Diffusion, International Review, 2016 No. 1-2, Faculty of Business Economics and Entrepreneurship, Belgrade, Medimond Bologna Italy, ISSN 2217-9739, pp. $142-152$

[9] Krstić M. (2013). Upravljanje inovacijama . Visoka škola za poslovnu ekonomiju i preduzetništvo, Beograd : ISBN 978-86-6069-84-7, COBISS.SR-ID 196935180, strana 169.

[10] Krstić, M., Skorup, A., Lapčević, G. (2016). Trendovi u razvoju inovativnih poslovnih modela,. Trendovi u poslovanju, Godina IV, Sveska 2., Br.8 (2016), str. 43-54, ISSN 2334816X, ISSN (Online) 2334-8356, http://trendovi.indmanager.org.

[11]Langdon M., Moses M., Po Chi W. (2014). AGILE INNOVATION, The Revolutionary Approach To Acclerate Success, Inspire Engagament \& Ignite Creativity . Wiley.

[12] Prasadi Lokuge, S.K. (2015). Agile Innovation: Innovating With Enterprise Systems. Doctor Thesis: Information Systems School Science and Engineering Faculty Queensland University of Technology.

[13] Rasmusson J. (2017). What is Agile? Retrieved from Agile In a Nutshell: http://www.agilenutshell.com/, 29.5.2017

[14] Rigby K. D, Sutherland J, Takeuchi H. (2016, b). Embracing Agile, 15.6.2017. Retrieved from https://hbr.org/2016/05/embracing-agile

[15] Rigby, K. D, Sutherland, J., Takeuchi, H. (2016,a). The Secret History of Agile. Retrieved from Harvard Business Review: https://hbr.org/2016/04/the-secret-history-of-agileinnovation, 31.5.2017

[16]Zakic, N., Bugarcic, M., Milovanovic, M. (2017), Proclivity for Open Innovation in the Case of Agricultural and Food Companies in Serbia, International Review, 2017 No. 3-4, Faculty of Business Economics and Entrepreneurship, Belgrade, Filodiritto Editore, pp.64-71

\section{Article history:}

- Received 5 March 2018

- Accepted 25 November 2018 